\title{
LA IGLESIA PALENTINA DE SAN PABLO: BREVE ESTUDIO SOBRE SUS RETABLOS (SIGLOS XV-XVII)
}

\author{
Ester Prieto Ustio* \\ Universidad de Sevilla \\ esterprieto@hotmail.com
}

\section{RESUMEN}

La iglesia palentina de San Pablo, situada en el centro neurálgico de la ciudad castellana, es un magnífico ejemplo para analizar la evolución artística desde el siglo XIII hasta el XVIII. Con el presente artículo, queremos llevar a cabo un breve estudio acerca de cinco de los retablos y enterramientos que forman o formaron parte del templo dominico, realizados entre los siglos XV y XVII, para comprobar la importancia que tuvo este espacio en la recepción de las principales tendencias artísticas europeas desarrolladas a finales de la Edad Media y comienzo de la Edad Moderna.

Palabras Clave: retablo, sepulcro, escultura, pintura, iglesia de San Pablo, Palencia.

\section{THE PALENCIA CHURCH OF SAN PABLO: \\ BRIEF STUDY ON ITS ALTARPIECES (15TH-17TH CENTURIES)}

\section{Abstract}

The church of San Pablo, located in the center of Palencia is a magnificent example to analyze artistic evolution from the $13^{\text {th }}$ to the $18^{\text {th }}$ centuries. With this article, we want to carry out a brief study about five of the altarpieces and tombs that form or were part of the Dominican temple, realized between the $15^{\text {th }}$ and $17^{\text {th }}$ centuries, to verify the importance of this space in the reception of the main European artistic trends developed at the end of the Middle Ages and the beginning of the Modern Age.

Keywords: altarpiece, tomb, sculpture, painting, San Pablo church, Palencia. 


\section{INTRODUCCIÓN}

La iglesia de San Pablo, ubicada en el corazón de Palencia, es desde sus orígenes la sede de la comunidad dominica en la ciudad castellana, la cual habita en un convento anexo al templo. Declarada Monumento Histórico-Artístico Nacional en $1931^{1}$, en el interior de sus pétreos muros custodia una destacada colección de pinturas, esculturas y artes decorativas realizadas entre los siglos XIII y xx (Pérez 1995).

Cabe señalar su papel en la historia, ya que durante la Edad Media fue sede de las Cortes Generales de Castilla en varias ocasiones y también acogió diversos Capítulos Generales de la Orden de Predicadores (Domínguez 2017).

El primitivo espacio monacal fue fundado entre 1219 y 1220 por el propio santo Domingo de Guzmán, siendo el segundo convento personalmente instaurado por el religioso (Medrano 1725). Esto fue debido a su vinculación personal con la ciudad, ya que el burgalés realizó su formación académica en el Studium Generale de Palencia, considerado como la primera universidad establecida en la Península Ibérica y una de las primeras del continente europeo, junto con París y Bolonia. Aunque la creación del centro de enseñanza se fecha entre 1208 y 1212 gracias a la iniciativa del ilustre obispo Tello Téllez de Meneses, se tiene constancia de su funcionamiento con anterioridad (Fuente 2012).

Actualmente, no queda ningún vestigio del antiguo convento, ya que fue ocupado como cuartel -al igual que la iglesia- por el ejército francés durante la Guerra de la Independencia y desamortizado en 1835 . Once ańos más tarde los dominicos volvieron a su sede, pero las dependencias conventuales fueron derruidas y durante las primeras décadas del siglo xx se erigió un nuevo edificio que sirviera de residencia para los religiosos (Quadrado 1865).

\section{EL TEMPLO}

La iglesia, en sus orígenes románica, sufre una completa remodelación entre los siglos XIV y XVI, siguiendo las directrices estilísticas del gótico tardío. Toda ella fue realizada con piedra de cantería muy bien trabajada, y se estableció un esquema de planta de tres naves, siendo la central más ancha y cubierta por bóvedas de crucería con combados y terceletes, mientras que en las laterales se aplicaron bóvedas de crucería simple. Sobre la nave de la epístola, se adosaron seis capillas laterales, mientras que en la nave del evangelio se conservan algunos restos del claustro gótico que estaba anexo al templo, así como la portada que permitía su acceso (Navarro 1946).

El exterior se presenta sencillo y austero, sin apenas decoración. Cuenta con dos puertas de entrada; la principal, situada a los pies de la parroquia, se fecha a finales del siglo XVIII con un carácter ya neoclásico y todavía un influjo escuria-

\footnotetext{
* Investigadora predoctoral. Universidad de Sevilla.

${ }^{1}$ Catálogo de Bienes Protegidos de la Junta de Castilla y León.
} 


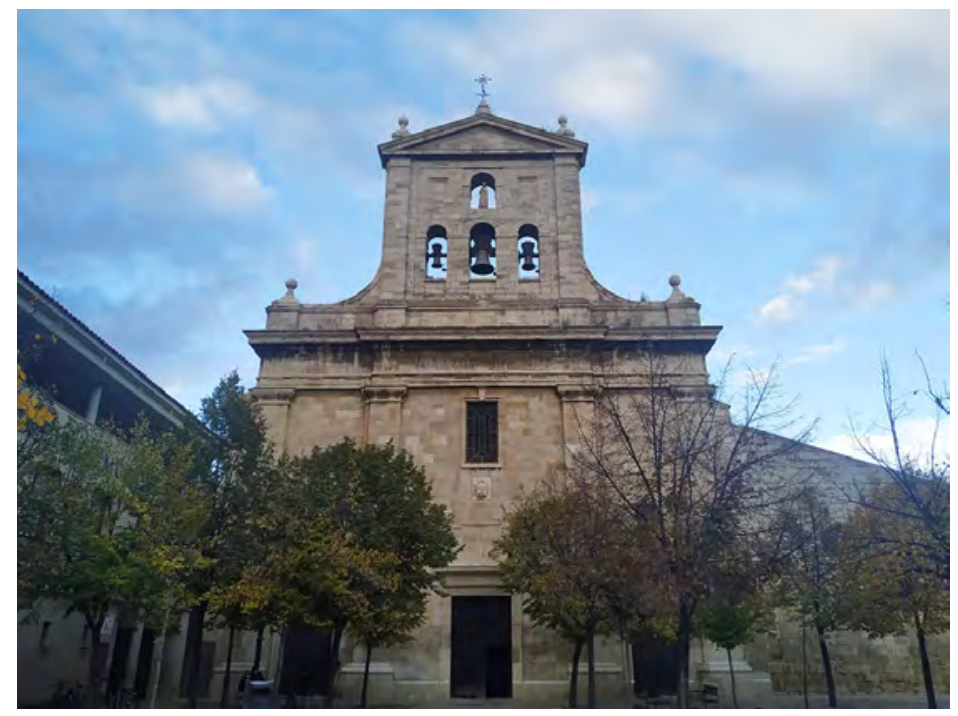

Fig. 1. Manuel Turrillo, iglesia de San Pablo (Palencia), fachada principal, finales del siglo XviIr. Fotografía: Ester Prieto Ustio.

lense. Formada por dos cuerpos, el inferior es una mole rectangular con tres puertas adinteladas, delimitadas por pilastras de orden toscano que ocupan toda la superficie. La parte superior se compone por una gran espadaña de líneas muy depuradas con cuatro hornacinas, una de ellas acoge una escultura de la Virgen de Fátima y las tres restantes contienen campanas. Se remata con un frontón triangular y dos aletones laterales decorados con bolas. El proyecto de remodelación de esta fachada, presentado por el arquitecto Manuel Turrillo, fue aprobado por la Comisión de Arquitectura de la Real Academia de Bellas Artes en 1787 (Saiz y Sánchez 2017)² (fig. 1).

Unos años antes de esta fecha, entre 1770 y 1771, se fecha el Estado general de las cofradias y hermandades de la ciudad de Palencia ${ }^{3}$, documento en el cual se recogen las cuatro agrupaciones asentadas en el convento de San Pablo, así como datos relativos a las mismas.

La cofradía Jesús Nazareno contaba con 80 hermanos en ese momento, llevaba a cabo una celebración anual y sus rentas eran de 1220 reales, mientras que sus gastos sumaban un total de 1114 reales.

2 El documento aparece compilado en Juntas de la Comisión de Arquitectura de 15 de octubre y 13 de diciembre de 1787, ARABASF, libro 3-139, fols. fol. 74 y 79. Referencia documental recogida en el artículo mencionado en el texto.

${ }^{3}$ Archivo Histórico Nacional, Consejos, 7097, Exp. 20, N. 1. 


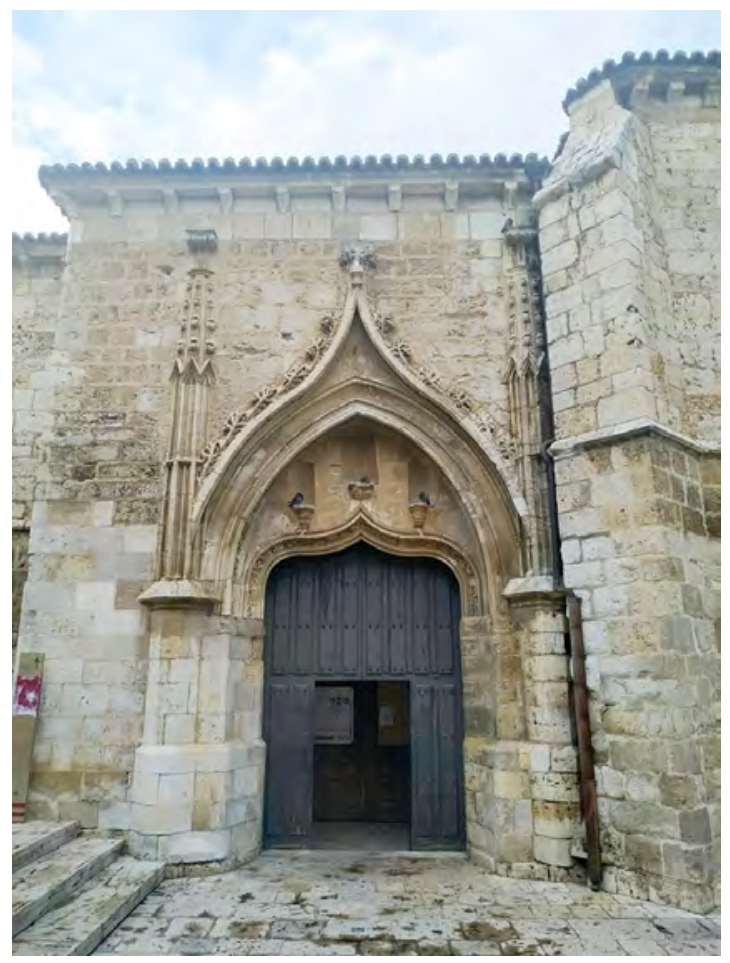

Fig. 2. Anónimo, iglesia de San Pablo (Palencia), fachada lateral, finales del siglo Xv-comienzos del Xvi. Fotografía: Ester Prieto Ustio.

La cofradía de la Santa Vera Cruz, con 1000 cofrades inscritos, constituía la segunda más popular en cuanto a miembros de la ciudad, por detrás de la de San Antonio Abad. Con un total de tres fiestas al año, sumaba 2653 reales de rentas y 2634 reales de gastos.

600 individuos formaban parte de la cofradía de Nuestra Señora del Rosario, la cual poseía 2672 reales en rentas, sus gastos ascendían a 3346 reales y celebraba una única fiesta anual.

La última cofradía con sede en el recinto dominico era la de las Ánimas del Camposanto de San Juan de Dios, cuyas rentas y gastos sumaban la misma cantidad, 2070 reales. Sus 380 cofrades organizaban una fiesta al ańo.

Volviendo al exterior del conjunto, su otra portada, abierta hacia el lado de la epístola, se llevó a cabo a finales del siglo Xv y comienzos del xvi. Consta de una combinación de arcos apuntados y conopiales, con decoración antropomórfica y vegetal entre sus arquivoltas, con todo el conjunto enmarcado entre pináculos laterales al modo de columnas, muy en consonancia con el dominado gótico isabelino o estilo Reyes Católicos (Martínez 1989) (fig. 2). 
Una de las grandes joyas de San Pablo es su capilla mayor. Realizada en sólida piedra con planta cuadrada, su parte exterior tiene un cierto carácter defensivo, contrastando con el interior, decorado con destacados ejemplos del arte renacentista espańol. El cubrimiento se lleva a cabo con una gran bóveda estrellada y combada, la cual acoge un destacado retablo plateresco. En los laterales de la capilla, se ubican los sepulcros de los I y iII marqueses de Poza, importantes benefactores tanto del templo como del convento. Estas tres obras conjugan los materiales más característicos del Renacimiento como la madera -retablo mayor-, la piedra-el sepulcro de los I marqueses de Poza-y el mármol -el nicho funerario de los III marqueses-, los cuales veremos con más detalle a lo largo de estas páginas.

En el presbiterio también se sitúa la sillería de coro, la cual originalmente se encontraba en el coro alto - a los pies de la iglesia-, pero tras reformas litúrgicas se traslada a la capilla mayor. Tallada en madera de nogal y ejecutada a finales del siglo XV y comienzos de la centuria posterior, cuenta con decoraciones vegetales y geométricas. Aparece en varias ocasiones el escudo de la familia Mendoza, y es que uno de sus más célebres miembros, Diego Hurtado de Mendoza, fue obispo de la Diócesis palentina entre 1471 y 1485 (García y Alonso 1981).

\section{BREVE CONTEXTO CULTURAL, PALENCIA: SIGLOS XV-XVII}

Desde finales del siglo XV y hasta comienzos del XVII, las ciudades castellanas de Palencia, Burgos y Valladolid vivieron un verdadero florecimiento económico gracias al comercio textil -especialmente del lanar-con Flandes, otros puntos de la Península e incluso América (Casado 2018), lo que ayudó a desarrollar grandes empresas artísticas en el ámbito civil, con la construcción de nuevas moradas para sus acaudalados propietarios, oratorios para la devoción particular, así como capillas de carácter funerario para funcionar como panteones familiares en los templos, y también en el ámbito religioso, ya que muchas órdenes religiosas ya asentadas en estas urbes emprendieron reformas en sus iglesias y conventos o incorporaron obras de arte adaptadas a las nuevas propuestas estéticas, de igual modo que hicieron los cabildos catedralicios.

Este auge monetario dio la posibilidad del establecimiento, ya desde el reinado de los Reyes Católicos, de una serie de artistas procedentes principalmente de las zonas flamencas, francesas y alemanas, como es el caso de Felipe Vigarny (Del Río 2000) y Juan de Juni (Fernández 2012), los cuales causaron una notabilísima influencia en artífices locales, al igual que la llegada de los modelos italianos a través de estampas, grabados y las estancias en tierras transalpinas de los castellanos Alonso Berruguete (Hoyos 2013) y Diego de Siloé (Gómez-Moreno 1963), quienes pudieron conocer de primera mano las ideas artísticas planteadas en la Italia del Cinquecento.

Palencia se convirtió en receptora de las tendencias propuestas en las escuelas burgalesa y vallisoletana, contando con la participación de los artistas más destacados de cada una de ellas en obras de la capital y los alrededores, pero también existieron dos talleres propiamente palentinos, el de Juan Ortiz el Viejo, discípulo 
de Vigarny y cuyo hijo, Luis Ortiz, será su sucesor al timón del obrador, y el de Juan de Valmaseda, ambos escultores muy activos en la primera mitad del siglo Xvi en la zona del Camino de Santiago palentino y la Tierra de Campos, como se puede observar en Población de Campos, Requena de Campos, Frómista o Carrión de los Condes, en cuyas iglesias se custodian piezas gubiadas por estos talleres (Portela 1977). También fue cuna de dos de los artistas más destacados del panorama renacentista español, Alonso y Pedro Berruguete, ambos nacidos en Paredes de Nava.

\section{LOS RETABLOS DE LA IGLESIA DE SAN PABLO: SIGLOS XV-XVII}

El templo palentino acoge entre sus muros una gran variedad retablística, pero vamos a centrar nuestro trabajo en el análisis de los retablos de Santa Úrsula, de la Piedad, retablo mayor y los sepulcros-retablos de los marqueses de Poza, en los que observaremos la evolución artística desde la pintura del gótico internacional hasta la escultura renacentista de influjos escurialenses.

\section{RETABLO DE SANTA ÚRSULA}

El que fuera el retablo dedicado a santa Úrsula y las once mil vírgenes, se conserva actualmente desmembrado y repartido por diversas partes del mundo. Según la historiografía (Pérez y Rodríguez 1995; Post 2014), en una fotografía ${ }^{4}$ realizada en el interior del convento de San Pablo en torno a 1879, posiblemente por Jean Laurent o algún artista de su entorno, se observaba un retablo barroco conformado por una escultura de san Pío V y una serie de paneles de clara factura gótica, los cuales fueron identificados como los procedentes de este malogrado conjunto al que nos vamos a referir, el cual estaría constituido en dos cuerpos con ocho tablas, una predela con siete compartimentos y cinco calles; en la central podría haberse ubicado una representación individual de la santa, según la reconstrucción realizada por Fernando Pérez y María Victoria Rodríguez (Pérez y Rodríguez 1995). Por su parte, Joaquín Yarza ha sugerido que, siguiendo las tendencias escultóricas del

${ }^{4}$ Dicha fotografía, según las investigaciones de Pérez y Rodríguez, 1995 y Post, 2014, forma parte del Archivo Ruiz Vernacci, compuesto por un numerosísimo conjunto de soportes fotográficos realizados entre 1858 y 1960, aglutinando producciones de fotógrafos como Jean Laurent, Catalina Melina Dosch, Alfonso Roswag, Joseph Jean Marie Lacoste Borde, Ángel Redondo de Zúńiga, Juana Roig Villalonga y el propio Joaquín Ruiz Vernacci. Este archivo fue adquirido en 1975 por el Estado español, y en la actualidad se encuentra integrado en la Fototeca del Instituto del Patrimonio Cultural de Espańa. Hemos consultado dichos fondos durante el mes de enero de 2020, pero no hemos encontrado la fotografía mencionada tanto por Pérez y Rodríguez como por Post, por lo que no podemos corroborar esta hipótesis. 
momento, es posible que una Crucifixión hubiese constituido el remate del ático (VV. AA. 1993).

Se ha mencionado que en 1909, las cuatro tablas inferiores del conjunto retablístico 5 se encontraban en manos de sir Francis Beaufort Palmer, experto británico en leyes y miembro del Burlington Fine Arts Club, aunque se desconoce cómo llegaron a formar parte de su colección. Diez años más tarde, las piezas salieron a subasta en la sede londinense de Christie's como el lote número 6, siendo adquiridas por la compañía Gooden \& Fox -posteriormente conocida como Hazlitt, Gooden \& Fox Ltd.-, conformada por los marchantes y asesores artísticos S.T. Gooden y F.W. Fox, para William Hesketh Lever, por un precio de 624 libras $^{6}$.

Antes de que Lever, vizconde de Leverhulme, quien compaginó su labor empresarial y política con la filantropía y el coleccionismo artístico, las incluyera en The Lady Lever Art Gallery -museo que fundó en 1922 en honor de su esposa Elizabeth, ubicado en Port Sunlight, Liverpool-, estas tablas fueron mostradas en exposiciones como la Spanish Old Masters, celebrada entre 1913 y 1914 en las galerías Graffton ${ }^{7}$ y en la Exhibition of Spanish Paintings, la cual se pudo visitar entre 1920 y 1921 en la Royal Academy of London ${ }^{8}$.

Las tablas superiores del retablo, «Petición de la mano de santa Úrsula, El embajador de Inglaterra da cuenta a su rey de los acontecimientos de su misión, Bautismo de Conan en presencia de Santa Úrsula y su padre y Llegada a Inglaterra de santa Úrsula", pertenecieron al coleccionista bilbaíno Antonio Gorostiza, aunque en 1992, el Museo Nacional del Prado las compró en la subasta celebrada en Sotheby's Madrid por la nada desdeñable suma de 79660000 de pesetas, cuantía económica posibilitada gracias los fondos procedentes del legado Villaescusa (VV. AA. 1993; VV. AA. 1995).

La predela del conjunto contenía siete imágenes de santos mártires emparejados, a excepción de una de las piezas, hoy en día en paradero desconocido, la cual, según las investigaciones de Charles Post, podía haber representado a santo Domingo (Post 2014).

Las tablas que muestran por un lado a santa Catalina y san Sebastián, y por el otro a santa Margarita y san Zoilo, fueron propiedad del célebre coleccionista y abogado americano John G. Johnson, quien legó sus más de mil obras artísticas a la ciudad de Filadelfia, con la condición de que éstas fueran expuestas en el que fuera su hogar. Aunque la Casa-Museo se inauguró en 1923, no permanecería muchos años abierta, ya que no tenía óptimas condiciones para la exhibición de las piezas, por lo que fueron transferidas al Philadelphia Museum of Art, donde se encuentran en la actualidad?

${ }^{5}$ Las cuales se corresponden con las representaciones de Santa Úrsula habla con las mártires, La llegada de Santa Úrsula a Roma, La condena a muerte de Santa Úrsula y El Martirio de Santa Úrsula.

${ }^{6}$ Sharples, J. (s.d.).

7 Graffton Gallery 1913.

${ }^{8}$ Royal Academy, 1920-1921.

9 Philadelphia Museum of Arts. 
La restante pintura de la predela, en la que aparecen san Bartolomé y santa María Magdalena, se ubica en el Zornmuseet -Mora, Suecia-, recinto museístico que acoge la casa y gran parte de la producción del pintor Anders Zorn, quien, además de ser un reconocido retratista, también adquirió obras artísticas para su residencia. Es posible que las pinturas de la iglesia de San Pablo fueran adquiridas en uno de sus frecuentes viajes a España, ya que existen constancias de que visitó en al menos ocho ocasiones la Península (Sandström 1992).

La autoría del conjunto retablístico -las ocho tablas del cuerpo y las seis de la predela- ha sido muy cuestionada desde su "redescubrimiento", ya que expertos como Mayer, Berenson y Post lo relacionaban con la escuela de Niza (Mayer 1915), la zona del Piamonte -con influencias de Jacques Durandi- (Berenson 1913) y la escuela catalana (Post 2014), respectivamente, aunque este último investigador, Charles Post, más adelante lo relacionó con las escuelas castellanas y aragonesas.

Por su parte, Gaya Nuño señaló que su autor podía ser el Maestro de Villamediana, activo en el ámbito palentino (Gaya Nuño 1958), pero tanto Gudiol como Yarza lo atribuyeron a la escuela valenciana y lo fecharon en torno a 1400-1410 (Yarza 1993), siendo el primero quien propuso las semejanzas estilísticas entre este conjunto y el retablo de san Jorge (Gudiol 1955) del Museo de Jérica (Castellón) -antes en la iglesia de misma advocación y realizado por Berenguer Mateu entre 1430-1431-.

Actualmente, tanto el Museo Nacional del Prado como The Lady Lever Art Gallery tienen sus piezas catalogadas como anónimas de la escuela valenciana; si bien la pinacoteca española las data entre 1425-1450, la británica retrasa su ejecución hacia 1400-1410. Por su parte, el Philadelphia Museum of Art cataloga las tablas como ejecución del valenciano Jaume Mateu en torno a 1450.

En todas las obras se pueden observar las principales características de la pintura gótica de la primera mitad del siglo xv, como el abundante uso del pan de oro, la concepción de figuras estilizadas, el movimiento en ropajes, así como la incorporación de detalles en la ambientación o en los fondos (Pitarch 1982).

La temática escogida tuvo una enorme difusión durante la Edad Media gracias a su inclusión en La Leyenda Dorada de Jacopo de la Vorágine, y en la propia ciudad castellana fue destacada, ya que en la seo palentina existía una capilla dedicada en exclusiva a santa Úrsula y las once mil vírgenes, en la cual se custodiaba la cabeza momificada de Córdula, la única doncella que escapó y se escondió de los hunos, pero arrepentida por no aceptar el martirio, se entregó a sus enemigos (Ferreiro 1991).

\section{RETABLO DE LA PIEDAD}

El primer retablo ejecutado en el siglo Xvi de la iglesia dominica es el que se sitúa en la Capilla de las Angustias, recinto que en su día perteneció a Gonzalo Zapata, deán del Cabildo de la catedral de Palencia desde 1479 hasta su fallecimiento en 1519.

Por el momento no se han encontrado testimonios documentales de los motivos por los que el religioso finalmente eligió el templo de San Pablo para su ente- 


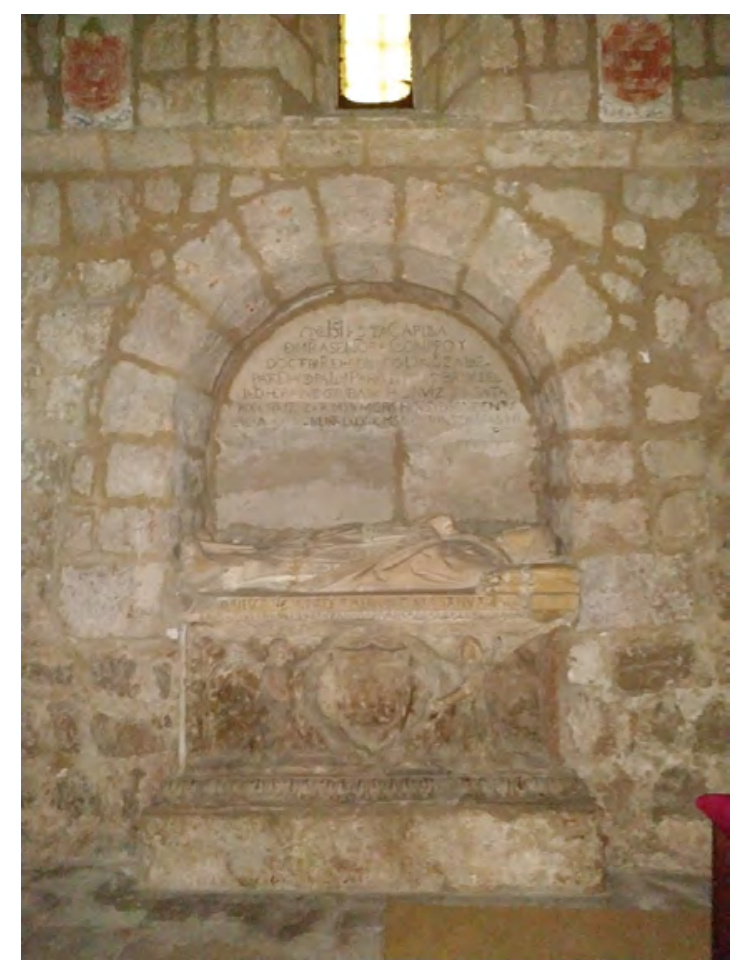

Fig. 3. Escuela castellana, sepulcro del deán Gonzalo Zapata, ¿1519? Fotografía: Ester Prieto Ustio.

rramiento y el de sus familiares, ya que se conserva una solicitud del 21 de junio de 1499 en la que ruega al Cabildo su inhumación en la seo palentina (Ara 1989).

Aún en vida, el deán Zapata emprendió toda una modificación del espacio para convertirlo en panteón familiar, llevando a cabo acciones como la incorporación de un arco de comunicación entre la capilla y el antiguo presbiterio, la ejecución del sepulcro y un retablo, así como el cerramiento de la misma, con una interesante reja fechada a comienzos del Quinientos y vinculada al taller de Alonso Relojero, en la que aún se observan elementos gotizantes, como el remate a modo de friso calado por dientes de sierra y arquillos, que se corona con un entrelazamiento de arcos conopiales (Andrés 1990).

La tumba del religioso se ubica en un arcosolio, en cuyo fondo aparece una inscripción en la que se indica su propiedad y patrocinio. En el frontal del conjunto, en mal estado de conservación, se sitúan dos ángeles portando el escudo de armas de la familia, y sobre un camastro se observa una escultura funeraria del deán yacente descansando sus manos en el pecho (fig. 3). 


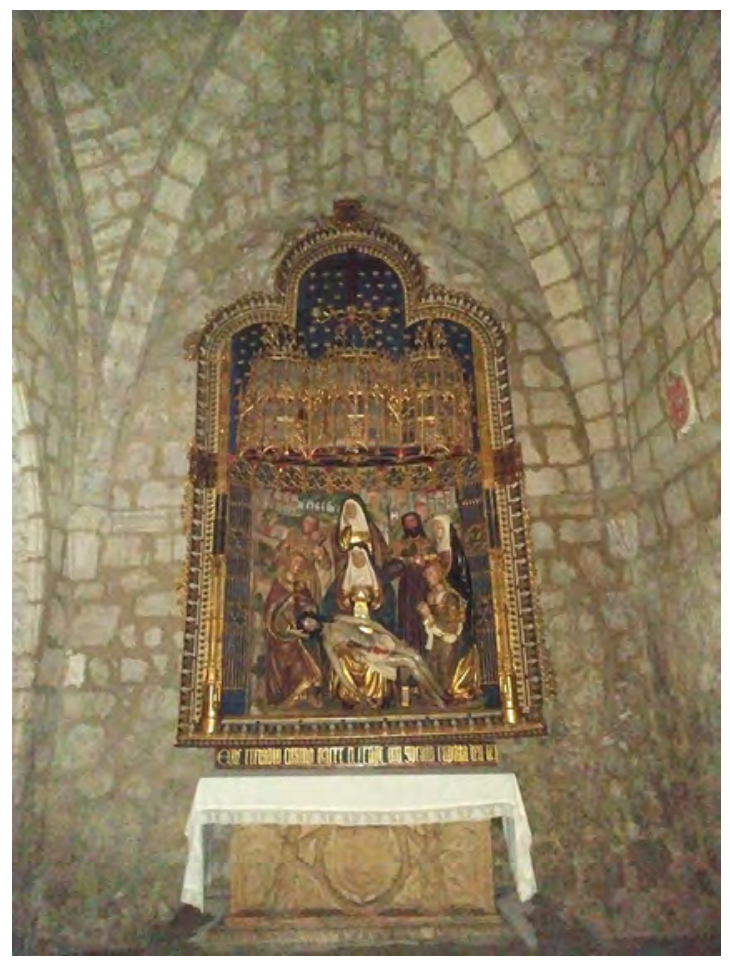

Fig. 4. Escuela castellana, retablo de la Piedad, iglesia de San Pablo (Palencia), 1516. Fotografía: Ester Prieto Ustio.

El retablo de la Piedad fue llevado a cabo en torno a 1516 (Quadrado 1885), $\mathrm{y}$ al igual que con el dispersado conjunto anterior, existen muchas dudas sobre su autoría, siendo vinculado por diversos expertos sobre escultura castellana al círculo de Felipe Vigarny, aunque la composición es demasiado arcaizante para los modelos que se trabajaban en esas fechas el taller del de Borgoña (Portela 1977). También se ha puesto en relación con el retablo mayor de la iglesia de Santa María de Dueñas, ejecutado entre 1510-1518 por Alonso de Ampudia, Pedro Manso y Antonio de Malinas (Martínez 2002), con claras trazas aún tardogóticas, sobre todo por los elementos arquitectónicos que enmarcan el retablo. Esta influencia aún medieval ha hecho que se piense en la atribución a Alejo de Vahía (Yarza 1987), o bien a algún taller del entorno vallisoletano (Ara 1974), pero no hay nada claro por el momento.

El original conjunto se compone de un altorrelieve que representa el Llanto sobre Cristo muerto, rematado por un juego arquitectónico de tracerías gotizante, sobre el que se coloca una cruz -quizás pudiera haber sido un Calvario o la representación de un Cristo en la cruz- y la representación celeste, enmarcado todo en un arco trilobulado (fig. 4). 


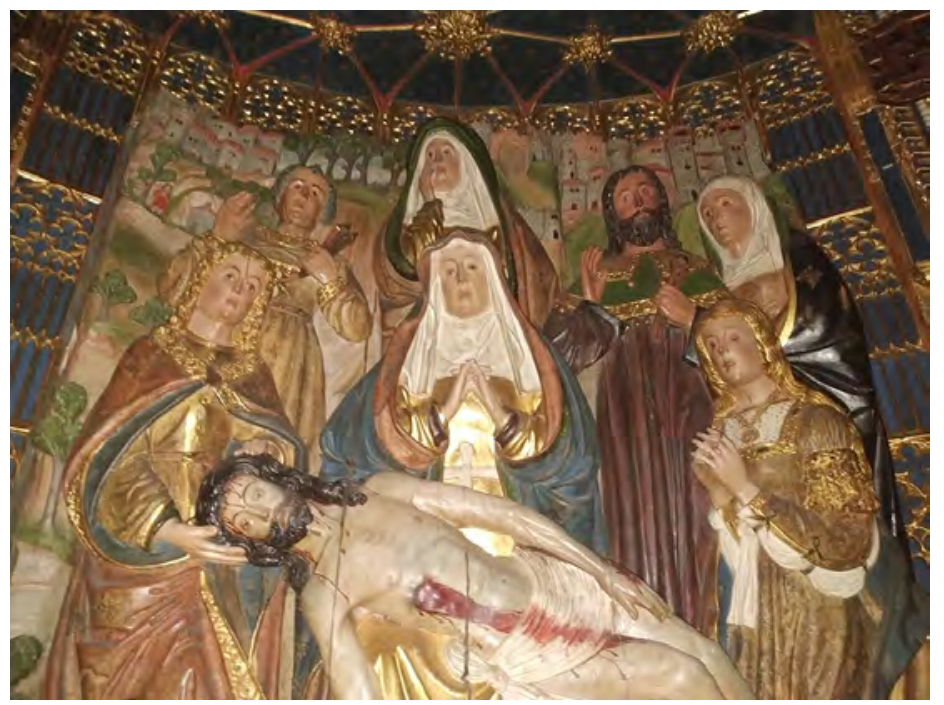

Fig. 5. Detalle de Escuela castellana, retablo de la Piedad, iglesia de San Pablo (Palencia), 1516. Fotografía: Ester Prieto Ustio.

Conformado en tres planos, el primero muestra a san Juan sustentando la cabeza de un Jesús ya muerto, mientras que la Virgen porta el cuerpo de su hijo en su regazo y María Magdalena, orante, se acompaña por el tarro de perfumes a sus pies. En el segundo, se representan las figuras de José de Arimatea, María Cleofás, Nicodemo y María Salomé, mientras que en el último podemos observar la entrada de una ciudad con una sensación de cierto abigarramiento.

El dramatismo de la escena se logra con la representación de los gestos de dolor en los rostros de los personajes, ciertamente alargados, con marcadas cejas, labios gruesos y carnaciones en los mofletes. También podemos comprobar el dinamismo con el movimiento de manos en el caso de Nicodemo, José de Arimatea -que portan los clavos y las tenazas que usaron para bajar a Jesús de la cruz- y María Salomé, así como el carácter realista de la figura de Cristo, con unas heridas muy sangrantes y un buen estudio anatómico de un cuerpo que cae sin vida, algo que será muy característico en Castilla (fig. 5).

Destacan las vestimentas, relacionadas con la moda de la época, como la capa que porta san Juan o el vestido brocado que lleva María Magdalena, quien viste de manera diferente que el resto de Santas Mujeres, ya que éstas se representan con grandes capas, pesadas túnicas y toca en la cabeza. Es muy interesante el tratamiento de los plegados, con una gran caída, lo que da mucha consistencia y corporeidad a las esculturas.

Existen composiciones similares, aunque de menor calidad artística, en otros puntos de la provincia, como en la iglesia de Santa Eugenia (Astudillo), en el tem- 


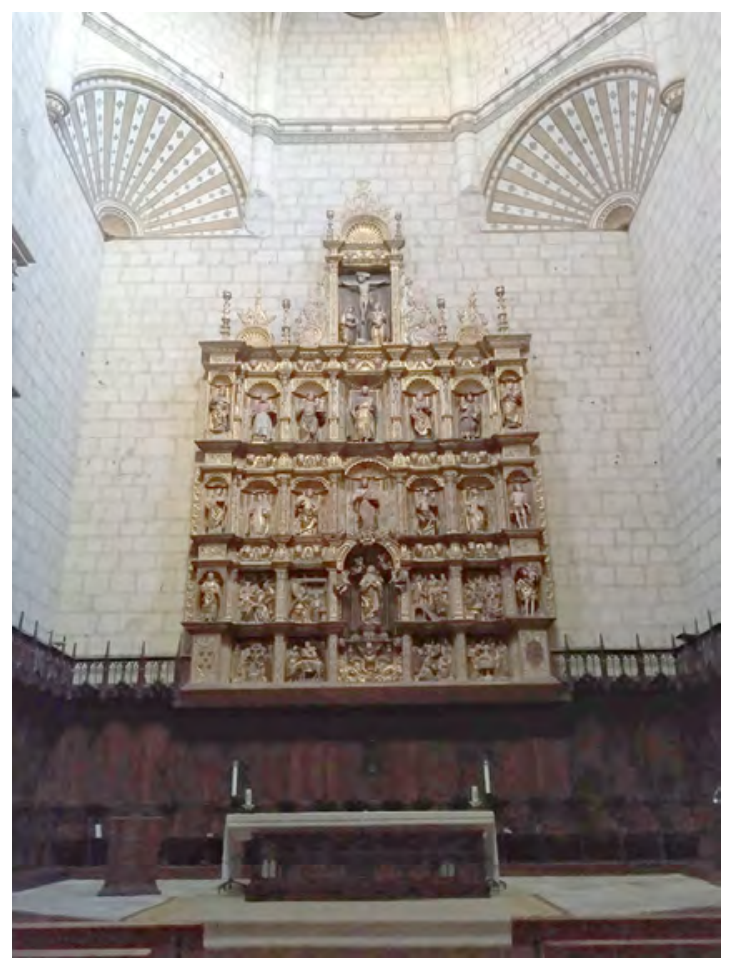

Fig. 6. Escuela castellana, retablo Mayor, iglesia de San Pablo (Palencia), ca. 1526. Fotografía: Ester Prieto Ustio.

plo de San Cornelio y San Cipriano (San Cebrián de Campos) o el ubicado en el Museo Diocesano y procedente de San Cebrián de Campos (Portela 1977).

\section{RETABLO MAYOR}

El retablo mayor de San Pablo, ejecutado alrededor de 1520 y atribuido tanto al círculo de Felipe Vigarny (Weise 1925, Proske 1952 y Azcárate 1958) como a Juan Ortiz el Viejo (Parrado 2003-2004 y Diccionario Biográfico electrónico de la Real Academia de la Historia), constituye una de las obras renacentistas más destacadas de la provincia (fig. 6).

Su principal modelo fue el propio retablo mayor de la catedral palentina (Revilla 1950), cuyas trazas fueron realizadas por Pedro de Guadalupe a partir de 1504 tras el encargo del obispo Diego de Deza, quien había contemplado el realizado por el mismo artífice en el Colegio de Santa Cruz de Valladolid. Las esculturas y pinturas que lo conforman fueron llevadas a cabo por los mejores artistas del 
ámbito castellano del momento, como Alejo de Vahía, Felipe Vigarny, Juan de Valmaseda, Juan de Flandes, y ya en el siglo XVII, Gregorio Fernández.

Este monumental retablo, con tres cuerpos, predela, ático y once calles separadas por pilastras, es uno de los primeros realizados siguiendo las directrices platerescas en toda España, y se convirtió en referencia para obras posteriores tanto en la ciudad como en los entornos vallisoletanos y burgaleses (Huerta 2001).

También el dominico se relaciona con el retablo de san Gregorio de la seo, ya que éste sigue un esquema muy plano, carece de doseles y sagrario, incorpora escenas coronadas con veneras y lo más destacado es la importancia de la escena principal, que ya comienza a sobresalir espacialmente (Payo y Martínez 2014).

El conjunto, al igual que el catedralicio, sigue una tipología «de casillero», debido a que las líneas verticales y horizontales se cruzan y cortan formando una retícula. Está compuesto por tres cuerpos compartimentados en siete calles verticales y articulados por pilastras sobre las que se elevan zócalos de querubines. Inferior y superiormente se remata con banco y ático, respectivamente (Andrés 1990).

La predela y el primer cuerpo presentan una serie de ocho relieves -cuatro en cada lado- que narran la infancia de Cristo y escenas de la vida de la Virgen: Presentación de María, Anunciación, Visitación, Nacimiento, Adoración de los Magos, Circuncisión, Huida a Egipto y Jesús entre los Doctores. Los relieves del banco son flanqueados por el escudo de la familia Rojas - patronos de la capilla mayor- y la Orden de los Predicadores.

En la parte central se abre una gran hornacina que acoge una imagen de la Asunción de la Virgen acompañada de cuatro ángeles, situada encima de una repisa decorada con un angelote y elementos propiamente renacentistas -tarjas entremezcladas con motivos vegetales-. En los extremos de los relieves -anexos a la escultura-, flanquean el cuerpo las imágenes de san Juan Evangelista y san Cristóbal.

El segundo y el tercer cuerpo se componen de figuras insertas en hornacinas aveneradas, representando a los santos más destacados de la orden dominica y de la devoción palentina. El cuerpo central -de izquierda a derecha- muestra a san Antolín, patrón de la ciudad; santa Catalina de Siena, portando su corazón en la mano y una corona de espinas sobre la testa; santo Domingo de Guzmán, el ilustre fundador del convento, acompañado de un perro con una antorcha en la boca; en el centro y de tamaño mayor aparece san Juan Bautista, acompañado por un cordero y la piel de camello; santo Tomás de Aquino, con el cuerpo de Cristo dentro de un cáliz y éste encima de un libro; san Pedro Mártir de Verona y san Sebastián.

En el último cuerpo se encuentra san Gregorio, con una paloma en su hombro; san Pío V, cuya escultura fue añadida posteriormente; san Antonio de Padua, acompañado del Nińo. En la zona central y de mayores dimensiones se coloca a san Pablo, titular del templo, junto con su atributo más destacado, la espada; santa Lucía, con una bandeja en la que porta sus ojos, como símbolo de su martirio; Santiago, ataviado como un peregrino, y santa Ana triple, acompañada por la Virgen y en Niño sobre sus rodillas.

El ático, de composición rectangular y delimitado por pilastras, se remata por un arco carpanel con una venera. En él se sitúa un Calvario, cuyo Cristo sirvió de inspiración para obras posteriores, como así se puede observar en el Crucificado 
realizado por Juan Ortiz para la iglesia de Nuestra Señora de la Asunción de Marcilla de Campos, y los situados en los templos de Castronuevo de Esgueva y Arrabal de Portillo, en la provincia de Valladolid (Parrado 2003-2004).

Las novedades que aporta este retablo son su acusada verticalidad gracias al uso de pilastras, el uso de cabezas de putti como elementos de separación en los frisos y la independencia del ático del propio corpus retablístico. Tanto las veinte esculturas -contando con el Calvario- como los ocho relieves comparten mismos aspectos formales, y al no contar con documentación sobre el encargo de esta obra, como ya hemos señalado, los especialistas han vinculado su hechura a Felipe Vigarny y su círculo más cercano, o a Juan Ortiz el Viejo. Ante la ausencia de datos documentales y no contar con una única teoría acerca de su autoría, lo que sí podemos afirmar es que quien realizó la pieza destaca por las cuidadas proporciones, la simetría corporal, la minuciosidad del estudio anatómico, rostros armónicos, el uso del contrapposto y monumentalidad en los ropajes -como mantos amplios a la manera de togas, plegados finos y crispados y paños que descienden hacia el suelo-.

Este retablo influyó en otras composiciones de la zona, como el que se encuentra en la capilla del sagrario de la catedral de Palencia, iniciado en 1529 por Ortiz, artistas de los círculos de Valmaseda y del propio Vigarny. También presenta una combinación de relieves y esculturas, utiliza pilastras y el ático goza de gran protagonismo, separándose del propio retablo. Las mismas características aparecen en el retablo mayor de la iglesia de San Cornelio y San Cipriano de San Cebrián de Campos, elaborado también por Juan Ortiz en fechas cercanas (De la Casa 2002).

\section{SEPULCRO-RETABLO DE LOS I MARQUESES DE POZA}

La capilla mayor de la iglesia de San Pablo fue utilizada como panteón familiar de los marqueses de Poza ${ }^{10}$. Juan de Rojas y Rojas, nacido en Monzón de Campos, recibió este título -antes señorío- por parte de Carlos V en 1537, convirtiéndose en el primero de su familia en ostentarlo. Casado con Marina de Villandrando ${ }^{11}$, hija de los condes de Salinas, fue un hombre fiel a la Corona incluso durante la revuelta comunera -en la que asaltaron su castillo burgalés de Mazuelo de Muñó-, por lo que sería nombrado alcalde y escribano mayor de los hijosdalgo en los reinos de Castilla, según la disposición firmada por Carlos I en $1548^{12}$ (fig. 7).

Antes de ostentar el marquesado, ya en 1514, De Rojas adquirió la capilla mayor del templo para su enterramiento, por lo que se llevó a cabo una remodelación espacial para adaptarla a las nuevas tendencias artísticas, así como al gusto del

${ }^{10}$ Entre los siglos XIV y XVI, esta capilla acogió las sepulturas de destacados personajes como don Nuńo González de Lara y su esposa, doña Teresa Alfonso, o lo señores de Montealegre, don Pedro Manuel y doña Juana Manrique (Andrés 1990).

${ }^{11}$ Las capitulaciones del enlace y los asuntos relacionados con la dote de Marina pueden consultarse en el Archivo Histórico de la Nobleza, Altamira, C.1, D.15.

12 Archivo de la Real Chancillería de Valladolid, Secretaría del acuerdo, Caja 2, 17. 


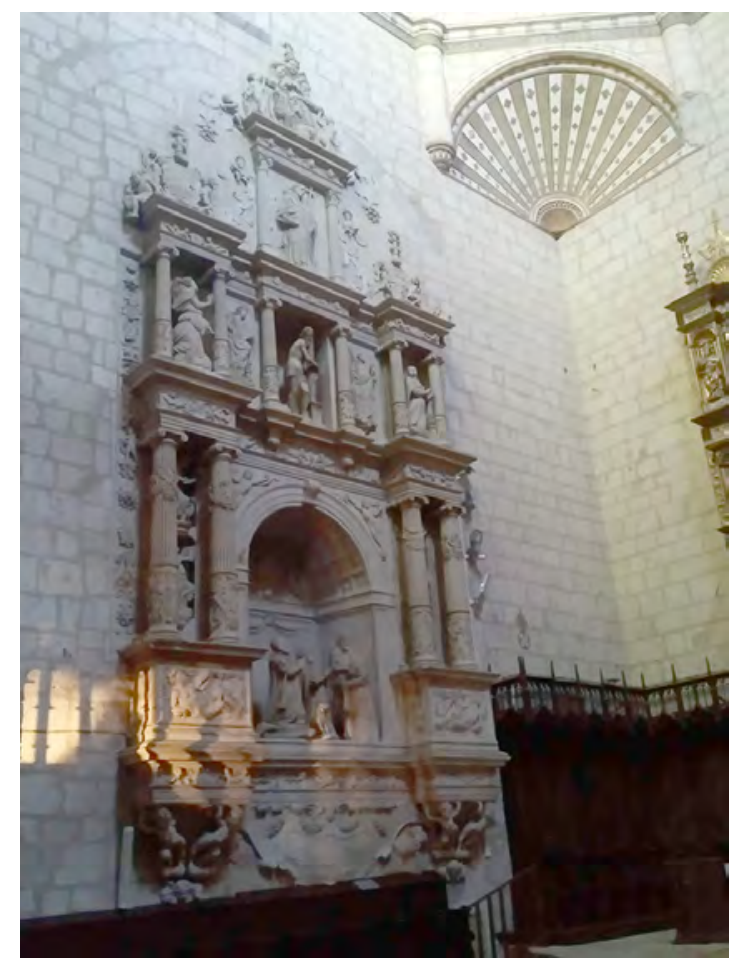

Fig. 7. Escuela castellana, sepulcro-retablo de los I marqueses de Poza, iglesia de San Pablo (Palencia), 1559. Fotografía: Ester Prieto Ustio.

noble, quien, además de su relación con este templo, dotó en 1556 de una capellanía a la iglesia del pueblo palentino de Valdespina ${ }^{13}$.

El sepulcro se finalizó en 1559 , y, al igual que con el resto de retablos de esta iglesia, su autoría siempre ha estado muy discutida, pensándose en Alonso Berruguete y Francisco Giralte (Salvador 1997), aunque en la actualidad se mantienen las teorías de Parrado del Olmo, atribuyéndose las trazas a Juan Sanz de Escalante y las esculturas a Manuel Álvarez y Juan Ortiz Fernández (Parrado 1981).

Hemos incluido esta pieza en nuestro breve estudio, ya que, aunque no es formalmente un retablo, la organización del enterramiento se lleva a cabo a la manera de éste, inspirándose tanto en modelos italianos como en el sepulcro de don Rodrigo de Mercado, conservado en la iglesia de San Miguel de Ońate, realizado por Diego de Siloé a finales de los años cuarenta del siglo Xvi (Andrés 1990). También su orga-

${ }^{13}$ Archivo Histórico de Nobleza, Altamira, C.1, D.33. 
nización recuerda a los esquemas arquitectónicos de las iglesias de San Miguel de Villarramiel o la parroquia de Tudela de Duero (Zalama 1987).

Como si fuera un arco triunfal, el conjunto se divide en dos cuerpos, tres calles, predela y ático, siendo sus materiales constructivos la piedra -probablemente procedente de la zona norte de la provincia, donde existían importantes canterasy alabastro.

El macizo basamento recoge las columnas superiores del cuerpo central por medio de unos remates sostenidos por putti, mientras que la parte central está formada por una cartela simulando una gran tarja, decorada con racimos de uvas y motivos a candelieri, en la que se puede leer la siguiente inscripción:

Aquí yace el muy ilustre Seńor D. Juan de Roxas, Marqués de Poza, y la muy ilustre Señora $\mathrm{D}^{\mathrm{a}}$. Marina Sarmiento su muger, el qual mandó hacer esta obra. Murió a primero de Agosto ańo de mil quinientos y cinquenta y ocho, acabose esta obra a diez y seis de Enero de mil quinientos y cincuenta y nuebe ${ }^{14}$.

En los laterales del primer cuerpo, a cada lado del enterramiento, aparecen dos columnas pareadas, con el fuste estriado y el tercio inferior tallado, las cuales se alzan sobre sólidas bases rectangulares, decoradas con relieves de alegorías, en la parte izquierda la Castidad y la Justicia, ambos personajes representados con sus principales atributos. En sus estrechos intercolumnios, encontramos hornacinas aveneradas en las que se sitúan los cuatro evangelistas. Las columnas son rematadas por un sistema de entablamento arquitrabado decorado por amorcillos (Parrado 1981).

La parte central se compone de un profundo arcosolio -formado por un arco de medio punto con el interior casetonado- en el que colocan las figuras orantes de Juan de Rojas y María Sarmiento, realizadas en alabastro, los cuales destacan por su realismo y el detallismo a la hora de representar los ropajes, los cuales eran la moda del momento. En los flancos del arco se representa un relieve de san Jerónimo penitente y otro de san Juan Bautista -patrón del marqués-. En el fondo del conjunto aparece un cortinaje, en cuyo tímpano observamos una Virgen acompañada del Niño y una serie de ángeles que portan las arma Christi.

Los laterales del segundo cuerpo son muy similares a los del anterior, aunque en este caso tienen una dimensión menor y hay más espacio en los intercolumnios, en los que se representa la Anunciación, situándose el arcángel Gabriel en el lado izquierdo y la Virgen en el derecho. El espacio central es idéntico a los laterales, aunque en él se sitúa una interesante escultura en alabastro de Cristo atado a la columna. Entre el cuerpo central y los laterales, aparecen dos relieves de dos de los santos dominicos por excelencia, santa Catalina de Alejandría y san Antonio de Padua (Redondo 1987).

El ático, trabajado con más planismo, se forma con dos columnas corintias con el fuste estriado, entre las cuales se ubica un altorrelieve del fundador de la

\footnotetext{
${ }_{14}$ Real Academia de la Historia.
} 
Orden, mientras que extremos aparecen los escudos de armas del matrimonio, y en la parte superior, la imagen de Dios Padre.

Esta tipología funeraria fue pionera en Palencia y su provincia, siendo el sepulcro de los I marqueses de Poza fuente de inspiración para otras obras, como se puede comprobar en el sepulcro de Fadrique de Acuña, conde de Buendía (López Yepes y López Yepes 1977), situado en la iglesia de Santa María de Dueñas y en el que también intervino Manuel Álvarez.

\section{SEPULCRO-RETABLO DE LOS III MARQUESES DE POZA}

Situado enfrente del enterramiento anterior, éste acoge los cuerpos de Francisco de Rojas y Enríquez y su esposa Francisca Enríquez de Almansa, terceros señores del marquesado de Poza.

Francisco ${ }^{15}$, nieto de Juan de Rojas, fue un destacado cortesano durante los reinados de Felipe II y Felipe III. Caballero de la Orden de Alcántara ${ }^{16}$, fue señor de Monzón, Cabia, Serón y Valdespina, alcalde mayor de los hijosdalgo de Castilla -cargo que también ostentó su abuelo, como acabamos de ver-, merino mayor de Burgos, presidente del Consejo de Hacienda ${ }^{17}$ y miembro del Consejo de Estado (Salazar y Castro 1697) (fig. 8).

El sepulcro fue encargado por Francisca, hija de los marqueses de Alcañices y gran benefactora del monasterio, ya que en su testamento otorgó al mismo un juro de 4500 maravedíes $^{18}$. Aunque su esposo falleció en 1605, el contrato para la construcción de su lugar de reposo tuvo lugar en 1609 en Valladolid entre la marquesa y los ensambladores Cristóbal y Francisco Velázquez, Antonio de Riera y Juan de Muniátegui, y el maestro cantero Antonio de $\mathrm{Arta}^{19}$. Parece ser que también colaboró en la obra Antonio Riera, pero su nombre no figura en la documentación del encargo. Antes de este encargo, la marquesa concertó la obra con el escultor Alonso de Vallejo, asentado en Madrid, pero se desconocen los motivos de la ruptura de este encargo (Martín 1958). Como hemos podido ir observando en este estudio, ésta es la única obra hasta el momento de la que se tiene constancia documental de su encargo y de los artistas que en ella trabajaron.

Con una marcada influencia de los Leoni, los hermanos Pompeo y Leone a partir de sus intervenciones en El Escorial (Martín 1951-1952) propusieron una

${ }^{15}$ Es posible que este personaje sirviera de inspiración al poeta Friedrich Schiller para la creación del personaje del marqués de Posa (o Poza) de la obra Don Carlos -1783-1787- y a su vez para la adaptación a la ópera que llevó a cabo Giuseppe Verdi en 1867 con Don Carlo.

${ }_{16}$ Archivo Histórico Nacional, OM-Caballeros_Alcantara, Exp. 1309.

${ }_{17}$ Muy interesante es la correspondencia al respecto de asuntos relacionados con este Consejo mantenida entre Rojas y Cristóvão de Moura e Távora, marqués de Castel-Rodrigo y virrey de Portugal. Biblioteca Nacional de España, Mss/6178.

${ }_{18}$ Archivo General de Simancas, CME, 783, 3.

19 Véase Anexo Documental (García, 1951). 


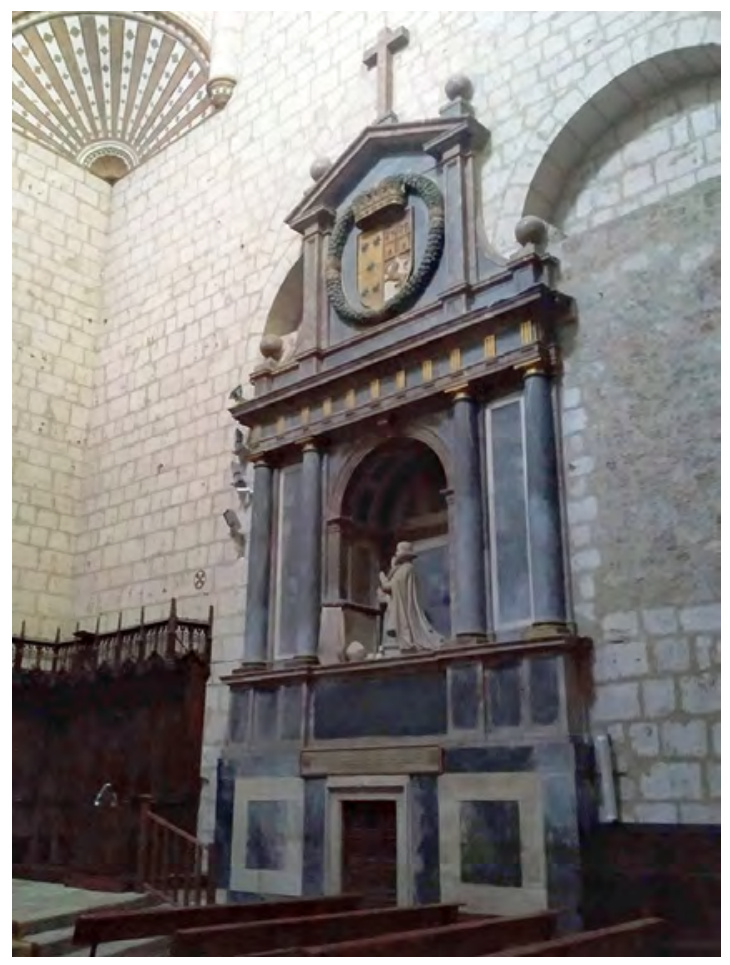

Fig. 8. Cristóbal y Francisco Velázquez, Antonio de Riera y Juan de Muniátegui, sepulcro-retablo de los II marqueses de Poza, iglesia de San Pablo (Palencia), ca. 1609. Fotografía: Ester Prieto Ustio.

vuelta a figuras más clasicistas, más estáticas, siguiendo un canon ciertamente idealizado, dotándolas de serenidad y distanciándose así de la tensión, los cánones alargados y las formas manieristas. A partir del retablo del monasterio madrileño-cuyas trazas fueron dadas por Juan de Herrera-, se prima la concepción arquitectónica, con espacios delimitados, una ausencia decorativa y se incorpora el uso de materiales como el mármol y el bronce.

El panteón de los marqueses, que sigue estas propuestas, es realizado en mármol, jaspe y bronce dorado, componiéndose de un único cuerpo dividido en tres calles y se acompaña de un gran ático y predela, primando la influencia de la arquitectura. En la parte más inferior del conjunto, se ubica una pequeña puerta por la que se accede a un reducido espacio donde están los cuerpos de los difuntos. Sobre ésta, aparece una sencilla predela con juegos cromáticos conseguidos con la combinación de jaspe y mármol en los laterales, y en la parte central se observa una inscripción con datos sobre los esposos.

Los laterales están formados por dos estrechas columnas muy clásicas, con el fuste liso de jaspe y rematadas en mármol y bronce. Los intercolumnios los com- 


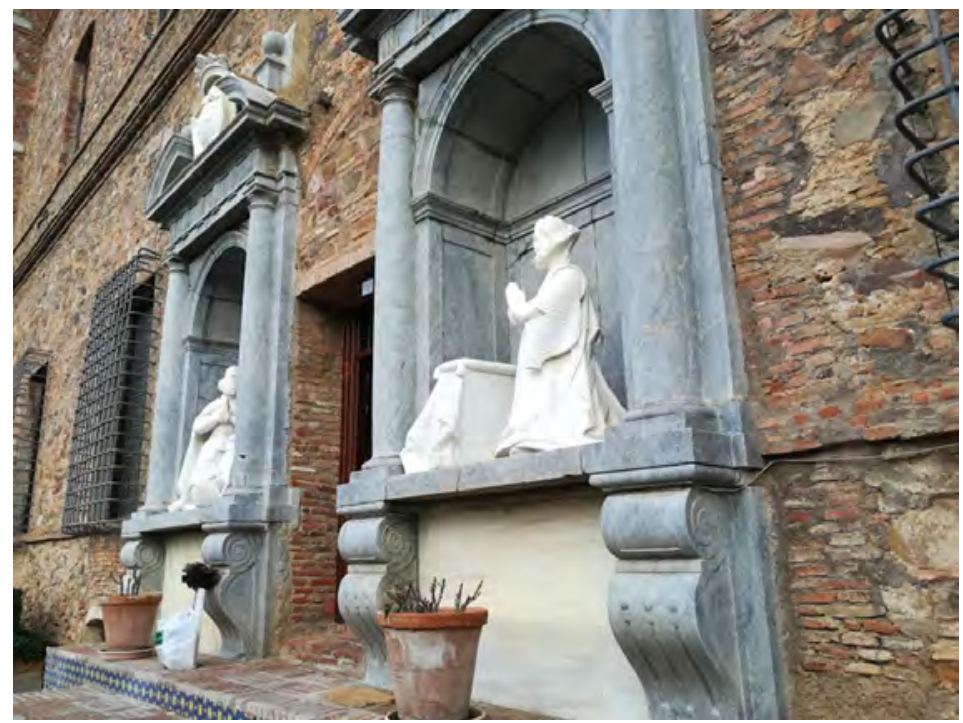

Fig. 9. Antonio de Riera, sepulcros de Alonso de Guzmán y María de Figueroa, Archivo-Museo Álvaro de Bazán (El Viso del Marqués), 1613. Fotografía: Ester Prieto Ustio.

ponen una combinación bícroma entre el verde jaspe y el mármol. Por encima de ellos se añade un sencillo entablamento con pequeñas aplicaciones verticales de bronce dorado.

El espacio central lo compone un arco de medio punto con profundidad, en el que se colocan las esculturas de los fallecidos. El matrimonio aparece rezando ante un pedestal marmóreo, vestidos a la moda cortesana de Felipe III, portando la popular gorguera. A los pies de Francisco se coloca un yelmo, aludiendo su pertenencia a una orden militar. El ático se remata con un frontón triangular, simulando una espadaña, acompañado por bolas de tradición escurialense. En él se coloca entre una guirnalda de motivos vegetales el escudo de la familia, único elemento que rompe con los materiales constructivos y los colores de la composición.

Esta obra inspiró el conjunto funerario de don Alonso de Guzmán y María de Figueroa, originariamente para el monasterio de Nuestra Señora de la Concepción de Viso del Marqués -Ciudad Real- (Marías 1978). Este enterramiento fue encargado al escultor Antonio de Riera en 1613, y actualmente se encuentra en los jardines del Archivo-Museo Álvaro de Bazán, edificio que fuera palacio de los marqueses de Santa Cruz (fig. 9). 


\section{CONCLUSIONES}

Como hemos podido ir observando a lo largo de este breve estudio, la actual iglesia palentina de San Pablo y exconvento dominico fue un destacado recinto de la ciudad a lo largo de la Edad Media y la Edad Moderna, tanto por las condiciones de su fundación, los acontecimientos allí desarrollados y los personajes que en él reposan como por las obras de arte que se custodian o custodiaron entre sus muros.

Durante los siglos XV y XVII, las más novedosas tendencias artísticas se dieron cita en este templo, desde la pintura gótica valenciana o la escultura gótica-flamenca, pasando por retablos renacentistas y enterramientos con claras dependencias italianizantes y escurialenses, estilos y ejemplos que ponen de manifiesto la relevancia de la ciudad en esas centurias.

Su situación geográfica, recursos naturales y económicos propiciaron que Palencia y su provincia se convirtieran, junto con Valladolid y Burgos, en un destacadísimo foco cultural en el cual se dieron cita artistas de muy diversas disciplinas y procedencias, además de ser cantera y lugar de nacimiento de importantes creadores del momento, por lo que la iglesia de San Pablo se convierte en un excelente paradigma para poder analizar la acusada evolución estilística desarrollada a lo largo de estos dos siglos, tránsito del Medievo a la Modernidad.

Recibido: 14 de febrero de 2020; ACeptado: 21 de septiembre de 2020 


\section{REFERENCIAS}

Andrés, S. (1990). «Los Dominicos en Palencia: El convento de San Pablo», en VV. AA. Jornadas sobre el arte de las Órdenes religiosas en Palencia. Palencia: Diputación Provincial de Palencia. pp. 71-110.

Ara, C. (1974). En torno al escultor Alejo de Vahía: 1490-1510. Valladolid: Universidad de Valladolid. $92 \mathrm{pp}$.

Ara, C. (1989). «La actividad artística en la catedral de Palencia durante los obispados de Diego Hurtado de Mendoza y Fray Alonso de Burgos (1471-1499)», en VV. AA. 1989. Jornadas sobre la Catedral de Palencia. 1 al 15 de agosto de 1988. Palencia: Diputación Provincial de Palencia. pp. 67-104

Atrins, C. (2018). The John G. Johnson Collection: A History and Selected Works. Philadelphia: Philadelphia Museum of Art. 845 pp.

Azcárate, J.M. (1958). Escultura del siglo XVI. Ars Hispaniae, vol. XIII. Madrid: Plus Ultra. 395 pp.

Berenson, B. (1913). Fichas números 260 y 261, en Graver Johnson, J. Catalogue of a Collection of Paintings and Some Art Objects (Johnson Collection), volumen I. Philadelphia: J.G. Johnson $488 \mathrm{pp}$.

CaSAdo, H. (2018). Comercio, finanzas y fiscalidad en Castilla (siglos XVYXVI). Barcelona: Midac. 340 pp.

De la Casa, E.M. (2002). «El retablo de la Piedad de San Cebrián de Campos». Publicaciones de la Institución Tello Téllez de Meneses. 73: 401-420.

Del Río, I. (2001). El escultor Felipe Bigarny, (h.1470-1542). Valladolid: Junta de Castilla y León, Consejería de Educación y Cultura. 450 pp.

Domínguez, S. (2017). El convento dominico de San Pablo de Palencia (1220-1600): breve reseña histórica y colección diplomática. Salamanca: San Esteban Editorial. 771 pp.

Esteban, A. y Valdeón, J. (1985). «Esbozo de una geografía social. Palencia a fines de la Edad Media». Studia historica. Historia medieval. 3: 117-142.

Fernández de Madrid, A. (1932). Silva palentina. Palencia: Imprenta de El Diario Palentino. 849 pp.

Fernández, M.A. (2012). Juan de Juni: escultor. Valladolid: Universidad de Valladolid, Secretariado de Publicaciones e Intercambio Editorial. 230 pp.

Ferreiro, J. (1991). La leyenda de las once mil virgenes: sus reliquias, culto e iconografía. Murcia: Editum. 340 pp.

Fuente, M.J. (1989). La ciudad de Palencia en el siglo XV. Aportación al estudio de las ciudades castellanas en la Baja Edad Media. Madrid: Editorial Universidad Complutense. 631 pp.

Fuente, M.J. (2012). La primera universidad hispana: el estudio general de Palencia. Palencia: Cálamo. $304 \mathrm{pp}$.

García, A. y Alonso, B. (1981). Synodicon Hispanum: Burgos y Palencia. Madrid: Biblioteca de Autores Cristianos. 800 pp.

García, E. (1951). Palencia. Papeletas de Historia y Arte. Palencia: Artes Gráficas Mazo 211 pp.

García. P. (1986). La Ciudad de Palencia en el siglo XIX: la desamortización y su transformación urbanistica (1836-1868). Palencia: Diputación Provincial de Palencia. 432 pp.

GaYa, J.A. (1958). La Pintura Española fuera de España. Historia y Catálogo. Madrid: España-Calpe. $371 \mathrm{pp}$. 
Gómez-Moreno, M. (1963). Diego Siloé: homenaje en el IV centenario de su muerte. Granada: Universidad de Granada. 105 pp.

González, J. (1984). Historia de Palencia. Palencia: Diputación Provincial de Palencia. 646 pp.

Graffton Gallery (1913). Illustrated catalogue of the exhibition of Spanish old masters in support of National Gallery funds and for the benefit of the Sociedad de Amigos del Arte Española, Oct. 1913 to Jan. 1914 [Internet]. En Internet Archive. [Cited 17 ene 2020]. Available from https://archive.org/details/illustratedcatal00grafiala/page/8/mode/2up.

Gudiol, J. (1955). La pintura gótica. Ars Hispaniae, vol. Ix. Madrid: Plus Ultra. 420 pp.

Hoyos, J. (2013). Alonso Berruguete, su obra e influencia: actas del curso de la Universidad "Casado del Alisal». Palencia: Diputación Provincial de Palencia. 191 pp.

Huerta, P.L. (2001). «Notas sobre el retablo mayor de la catedral de Palencia». Pátina, 10-11: 240-259.

Junta de Castilla y León [Internet]. En Catálogo de Bienes Protegidos de la Junta de Castilla y León [cited 18 ene 2020]. Available from https://servicios.jcyl.es/pweb/datos.do?numero= 7558\&tipo=Inmueble\&ruta $=$.

López Yepes, A. y López Yepes, J. (1977). «El Monte de la Piedad de Dueńas (Palencia) fundado por D. Fadrique de Acuña, Conde de Buendía (c. 1550)». Boletín de documentación del Fondo para la Investigación Económica y Social, 9-2: 364-388.

Marías, F. (1978). "Antonio de Riera en El Viso del Marqués». Boletín del Seminario de Estudios de Arte y Arqueología. 44: 477-478.

Mayer, A. (1915). «Die spanischen Azulejos und ihre Bedeutung für die Erforschung der Quattrocentomalerei». Der Cicerone: Halbmonatsschrift für die Interessen des Kunstforschers \& Sammlers. 7: 66-70.

Martín, J.J. (1951-1952). «Sobre la intervención de León Leoni en el retablo del Escorial». Boletín del Seminario de Estudios de Arte y Arqueología. 18: 126-127.

Martín, J.J. (1958). Escultura barroca castellana. Madrid: Fundación Lázaro Galdiano. 425 pp.

Martínez, R. (1989). La arquitectura gótica en la ciudad de Palencia (1165-1516). Palencia: Diputación Provincial de Palencia. 270 pp.

Martínez, R. (2002). «Pedro Manso y el retablo mayor de la iglesia parroquial de Dueńas (Palencia)». Publicaciones de la Institución Tello Téllez de Meneses. 73: 421-428.

Medrano, M.J. (1725). Historia de la provincia de España de la Orden de Predicadores. Madrid: Oficina de Don Gabriel del Barrio. 2119 pp.

Milicua, J. (1954). Palencia Monumental. Madrid: Plus Ultra. 155 pp.

Ministerio de Educación, Cultura y Deporte [Internet]. En Fototeca del Patrimonio Histórico: Gobierno de España [cited 1-31 ene 2020]. Available from http://www.mcu.es/fototeca_patrimonio/search_fields.do?buscador=porCampos\&limpiar=true.

Museo Nacional del Prado [Internet]. Petición de la mano de Santa Úrsula, en Colección Museo del Prado [cited 15 ene 2020]. Available from https://www.museodelprado.es/coleccion/obrade-arte/peticion-de-la-mano-de-santa-ursula/784f99ae-002a-4bd7-92b9-a3f511e1e890.

Navarro, R. 1946. Catalogo Monumental de la Provincia de Palencia. Fascículo Cuarto: Partido Judicial de Palencia. Palencia: Diputación Provincial de Palencia. 213 pp.

Parrado, J.M. 1981. Escultores seguidores de Berruguete en Palencia. Valladolid: Ediciones Universidad de Valladolid. 485 pp.

Parrado, J.M. (2003-2004). «Sobre algunas esculturas del siglo XVI». Boletín del Seminario de Estudios de Arte y Arqueología. 69-70: 303-320. 
Payo, R. y Martínez, R. (2011). La catedral de Palencia. Catorce siglos de historia y arte. Burgos: Promecal Publicaciones. 632 pp.

Pérez, F. y Rodríguez, M.V. (1995). «Iconografía de Santa Úrsula en Palencia el retablo de San Pablo de Palencia», en Calleja González, M.V., coord. Actas del III Congreso de Historia de Palencia: 30, 31 de marzo y 1 de abril de 1995. Palencia: Diputación Provincial de Palencia. pp. 763-772.

Pérez, M. (1995). «Cálices de convento de San Pablo de Palencia». Publicaciones de la Institución "Tello Téllez de Meneses». 66: 321-336.

Philadelphia Museum of Arts [Internet]. Predella panel showing Saints Margaret and Bartholomew. En Collections of Philadelphia Museum of Arts [cited 18 ene 2020]. Available from https://www.philamuseum.org/collections/permanent/102018.html?mulR=1953409991|36.

Philadelphia Museum of Arts [Internet]. Saints Sebastian and Catherine of Alexandria. En Collections of Philadelphia Museum of Arts [cited 18 ene 2020]. Available from https://www.philamuseum.org/collections/permanent/102017.html?mulR=1253344118|47.

Pitarch, A. (1982(. Pintura gótica valenciana: el periodo internacional (desde la formación del Taller de València, ca. 1374, hasta la presencia de la segunda corriente flamenca, ca. 1440-1450). Barcelona: Edicions Universitat de Barcelona. 38 pp.

Portela, F.J. (1977). La escultura del siglo XVI en Palencia. Palencia: Diputación Provincial de Palencia. 488 pp.

Post, C. (2014). A History of Spanish Painting. Volume IV-Part. 1. The Hispano-Flemish Style in NorthWestern Spain. Cambridge: Harvard University Press. 364 pp.

Proske, B.G. (1952). Castilian Sculpture, Gothic to Renaissance. Nueva York: Hispanic Society of America. 525 pp.

Quadrado, J.M. (1865). Recuerdos y bellezas de España. Valladolid, Palencia y Zamora. Madrid: Imprenta de López. 434 pp.

Quadrado, J.M. (1885). España. Sus monumentosy su arte, su naturaleza e historia. Valladolid, Palencia y Zamora. Barcelona: Establecimiento Tipográfico-editorial de Daniel Cortezo y C. ${ }^{a}$. 669 pp.

Real Academia de la Historia [Internet]. Relación de varios sepulcros de la familia de Rojas, marqueses de Poza, en el convento de San Pablo de Palencia. En Biblioteca Digital Real Academia de la Historia [cited 18 ene 2020]. Available from http://bibliotecadigital.rah.es/es/ consulta/registro.do?control=RAH20112010546.

Real Academia de la Historia. Diccionario Biográfico electrónico [Internet]. Juan Ortiz [cited 19 ene 2020]. Available from http://dbe.rah.es/biografias/57367/juan-ortiz.

Redondo, M.J. (1987). El sepulcro en España en el siglo XVI. Madrid: Centro Nacional de Información y Documentación del Patrimonio Histórico. 443 pp.

Revilla, R. (1950). Retablo mayor de la Santa Iglesia Catedral de Palencia. Publicaciones de la Institución Tello Téllez de Meneses. 5: 91-104.

Royal Academy (1920-1921). Exhibition of Spanish Painting, 3 November 1920 to 15 January 1921. [Internet]. En Arts \& Artists: Royal Academy of Arts [cited 17 ene 2020]. Available from https://www.royalacademy.org.uk/art-artists/exhibition-catalogue/1920-21-exhibition-of-spanish-painting.

SAiz, J.L y SÁnchez, J.I. (2017). «La iglesia parroquial de Guaza de Campos (Palencia) y la influencia de la Academia de San Fernando en su proyecto». BSAA arte. 83: 253-276. 
Salazar y Castro, L. (1697). Historia Genealógica de la Casa de Lara justificada con instrumentos, y escritores de inviolable fe, volumen 2. Madrid: Imprenta Real (impresor Mateo de Llanos y Guzman). $891 \mathrm{pp}$.

Salvador, J. (1997). Los conventos de Dominicos en la provincia de Palencia. Palencia: Diputación Provincial de Palencia. 598 pp.

Sharples, J. (s.d.). The National Inventory of Continental European Paintings [Internet]. En VADS: Univerity fot the Creative Arts (UK) [cited 15 ene 2020]. Available from https://vads.ac.uk/ large.php?uid $=243034 \& \operatorname{sos}=0$.

Sandström, B. (1992). «Zorn y España», en VV. AA. Sorolla-Zorn. Madrid: Ministerio de Cultura. pp. 39-48.

Urrea, J. y Martínez, R. (1978). «Construcción, proceso y derribo del arco del Mercado de Palencia (1784-1909)». Boletín del Seminario de Estudios de Arte y Arqueología Valladolid, vol. 44: 510-516.

VADS: University for the Creative Arts, NICE Paintings-National Inventory of Continental European Paintings (UK) [Internet]. Santa Úrsula habla con las mártires, en Lady Lever Art Gallery, Port Sunlight [cited 15 ene 2020]. Available from https://www.vads.ac.uk/digital/ collection/NIRP/id/30735.

VADS: University for the Creative Arts, NICE Paintings-National Inventory of Continental European Paintings (UK) [Internet]. La llegada de Santa Úrsula a Roma en Lady Lever Art Gallery, Port Sunlight [cited 15 ene 2020]. Available from https://www.vads.ac.uk/digital/ collection/NIRP/id/30869.

VADS: University for the Creative Arts, NICE Paintings-National Inventory of Continental European Paintings (UK) [Internet]. La condena a muerte de Santa Úrsula en Lady Lever Art Gallery, Port Sunlight [cited 15 ene 2020]. Available from https://www.vads.ac.uk/digital/ collection/NIRP/id/30038.

VADS: University for the Creative Arts, NICE Paintings-National Inventory of Continental European Paintings (UK) [Internet]. El Martirio de Santa Úrsula en Lady Lever Art Gallery, Port Sunlight [cited 15 ene 2020]. Available from https://www.vads.ac.uk/digital/collection/NIRP/id/30069.

VV. AA. (1989). Jornadas Sobre La Catedral de Palencia. 1 al 15 de agosto de 1988. Universidad de Verano Casado del Alisal. Palencia: Diputación Provincial de Palencia. 314 pp.

VV. AA. (1993). Un mecenas póstumo: el legado Villaescusa: adquisiciones 1992-1993. Madrid: Museo del Prado. 133 pp.

VV. AA. (1994). Paintings from Europe and the Americas in the Philadelphia Museum of Art: A Concise Catalogue. Philadelphia: Philadelphia Museum of Art. 548 pp.

VV. AA. (1995). Últimas adquisiciones: 1982-1995. Madrid: Museo del Prado. 124 pp.

Weise, G. (1925). Spanische Plastik Aus Sieben Jahrhunderten. Reutlingen: Gryphius. 251 pp.

YArZA, J. (1987). "Definición y ambigüedad del tardogótico palentino», en VV. AA. Actas del I Congreso de Historia de Palencia. Castillo de Monzón de Campos, 3-5 diciembre de 1985. Palencia: Diputación Provincial. pp. 23-60.

Yarza, J. (1993). "Cuatro escenas de la vida de Santa Úrsula», en VV. AA. Un mecenas póstumo: el legado Villaescusa: adquisiciones 1992-1993. Madrid: Museo del Prado. pp. 12-19.

Zalama, M.A. (1987). «Portadas retablo renacentistas en. Valladolid y Palencia». Boletín del Seminario de Estudios de Arte y Arqueología. 53: 312-316. 


\section{ANEXO DOCUMENTAL}

\section{Contrato para la realización del sepulcro de los iit marqueses de Poza}

Información recopilada por Esteban García Chico en Papeletas de Historia y Arte. Palencia: Artes Gráficas Mazo, 1951, pp. 133-137 y por Anastasio Rojo Vega en el blog https://investigadoresrb. patrimonionacional.es/node/9060.

Doña Francisca Enríquez de Cabrera [...] biuda del señor don francisco de rojas marques de poça del consejo de estado y guerra de su magestad [...] hizo concierto con Cristóbal Velázquez, su hijo Francisco Velázquez y Juan de Muniategui, maestros ensambladores; y Antonio de Arta, maestro cantero, sobre una capilla en Palencia. [...] que los dichos cristobal y francisco velazquez juan de monategui y antonio de arta como tales maestros y escultores toman a su cargo y riesgo y debajo de la dicha mancomunidad y renunciaciones de ley se obligan de acer y que aran en la capilla mayor del monesterio de san pablo de la ziudad de Palencia de la orden de santo domingo cuya fundaçion y patronazgo es de los dichos señores don francisco de rojas y dońa francisca enriquez su muger marques y marquesa de poça un nicho en que en ancho y alto sea igual con el que esta hecho en la dicha capilla al lado del ebangelio donde estan los bultos de los señores marques y marquesa de poça don juan de rojas y dońa maria sarmiento y como lo demuestra una traça que dello esta hecha y firmada del señor contador juan de sabanza en nombre y por la dicha seńora marquesa [...] de la forma y con las condiciones siguientes: primeramente an de acer un çocalo de marmol blanco y negro de las canteras de estremoz como lo demuestra la dicha traça yten an de açer encima deste çocalo un pedestal sobre que cargan las colunas con su basa y sotabasa de jaspe colorado y los entrepaños de marmol blanco y negro como lo muestra la dicha traça yten que la piedra donde a de ir el letrero a de ser de marmol negro yten an de acer cuatro colunas de marmol blanco y negro de doce pies de alto con sus basas y capiteles de bronçe dorado y entre coluna y coluna an de echar un entrepaño de marmol negro con sus fajas de jaspe y los traspilares de jaspe todos con sus capiteles y basas de bronçe yten que el dicho nicho a de tener siete pies de ancho y quatro de ondo desde el bibo del traspilar guarnecido con sus pilastras como lo muestra el alçado y plata de la traça mas a de llebar por la parte de adentro del nicho quatro pilastras de jaspe enbutidas de marmol negro y entre pilastra y pilastra guarnecido de jaspe y marmol y las pilastras an de llebar la inposta resaltada como lo muestra la traça y de pilastra a pilastra an de cerrar dos arcos de jaspe el delantero que sale a la capilla con sus molduras como lo muestra la traça y el de adentro sin molduras las dobelas destos arcos an de ser inbutidas de marmol muy bien ajustado y pegados con su betun de fuego yten an de acer el cornizamento desta obra de orden dorica con las gotas del alquitrabe de bronçe dorado y los trilifos del friso de bronçe dorado con metopas de marmol y su alquitrabe y corniza de jaspe como lo muestra la traça mas an de acer sobre la corniza un pedestal de jaspe y marmol como lo muestra la traça yten an de acer e elijir sobre este pedestal sus pilatras de jaspe enbutidas de marmol con basas y capiteles de bronçe dorado con sus basas y arbotantes yten an de acer un escudo de armas con su corona con las armas que les señalaren y su feston alrededor muy bien adornado yten an de acer su frontespiçio con sus bolas y pedestales de jaspe como le muestra la traça yten an de acer debajo del dicho nicho una caja con su arco donde a de cargar la figura que quepa un onbre a andar alla dentro y la entrada sera quitando una piedra del çocalo para meter un ataud la qual dicha obra y las piedras della an de ser de jaspe colorado de las canteras de espeja y el marmol blanco y negro de las canteras de estremoz que es en el reino de portugal todo ello muy bien enbutido y labrado e ilustrado a contento de la persona que para ello señalare la seńora marquesa y toda la obra a de ir muy bien asentada con sus grapas donde fuere necesario y los enbutidos con su betun de fuego pegados y muy bien ajustados yten mas an de acer los dichos maestros un bulto de siete pies de alto puesto en pie de la figura del señor marques con el adorno que muestra la traça de marmol de las canteras de estremoz de una piedra sola sin añadidura ninguna y sin pico que la yenda por ninguna parte ni respentadura 
ni entrecascado y con su almuada de marmol blanco y las borlas de bronçe doradas y el sitial de marmol blanco todo ello conforme al retrato que esta en la dicha traça y a contento de su señoria yten que encima del frontespicio se a de acer un pedestal y encima una cruz de jaspe de quatro pies de alto conforme a la traça yten que todos los claros que sobraren a los lados deste nicho se an de inchir de piedra labrada como esta lo demas de la capilla yten que en el pedestal de debajo del nicho en la lamina de marmol negro se a de esculpir en letras de bronce doradas metidas en la misma lamina el letrero que se sigue «aqui yace don francisco de rojas marques de poça de los consejos destado y guerra de los señores reyes don felipe segundo y terçero falleçio a trece de henero de mil y seiscientos y quatro hiço esta obra doña francisca enriquez de cabrera su muger hija de los seńores almirante de castilla duques de medina de rioseco y condes de modica don luis enriquez y dońa ana de cabrera y tanbien hiço la reja y doto la misa mayor conbentual en seiscientos ducados en cada un año perpetuos con que los trecientos ducados se an de enplear en cada un ańo para aumento de la dicha memoria y dotacion acabose tal dia" y que las letras del dicho letrero an de ser del tamańo y de la manera questan escritas en un patron de papel de marca mayor y esta firmado del dicho señor contador juan de sabanza y de los tres maestros y del presente scrivano que queda en poder del dicho contador yten que el padre prior del dicho conbento a de dar parte acomodada y cerrada donde se labre y guarde el jaspe y marmol para la seguridad y comodidad de la obra yten que los dichos maestros se encargan y se obligan quando començaren la dicha obra a cubrir la rela con lienço de manera que no resciba dańo con el polbo y si lo rescibiere a de ser a su costa y por su quenta lo an de adreçar y cubrir la dicha reja yten que los dichos maestros an de quitar los antepechos que estan en la capilla y alargar las gradas y escodar las demas para que parezcan todas nuebas y todo lo demas que fuere necesario para asentarlas lo an de acer los dichos maestros a su costa sin que la dicha señora marquesa les aya de dar cosa alguna de materiales ni manos para ello las quales dichas gradas an de estar hechas para el dia de todos santos primero que biene deste presente año de mil y seiscientos y nuebe yten que toda la dicha obra la an de acer sin perjuicio ni daño de lo que esta hecho y quedando todo el edificio y obra con la seguridad y firmeça necesaria por quanto se a de abrir para acer la dicha obra y tomar parte de los dos arcos por quanto no cave en uno que lo que sobrare de los dichos dos arcos se a de cerrar de la misma piedra y el nicho que se ace de nuebo a de imitar en alto y ancho sin tener mas ni menos al que esta hecho enfrente del y al ornato del yten que toda la dicha obra conforme a la dicha traça y condiciones y en la manera que dicha es la daran hecha y acabada en toda perficion dentro de dos años contados desde oy dia de la fecha desta escritura en adelante yten que toda la dicha obra conforme a la dicha traça y condiciones y en el dicho tiempo la an de acer los dichos maestros a toda su costa ansi de manos como de materiales a los plaços que iran declarados sin que su seńoria sea obligada a darles otra cosa alguna yten que si los dichos maestros dieren acavada la dicha obra y puesta en perficion antes de los dichos dos ańos por cada mes que la anticiparen se les aya de dar cien ducados mas del preçio questa concertado yten con condiçion que si los dichos maestros no cunplieren pusieren y asentaren y acavaren la dicha obra en perficion dentro de los dichos dos años se les aya de bajar mil ducados del dicho precio y que demas desto su seńoria pueda poner a costa de los dichos maestros personas que lo acaben a contento de su señoria y por el precio en que se concertare [...] yten con condicion que despues de acabada y puesta en perficion la dicha obra la dicha señora marquesa pueda poner persona o personas a satistafion de su seńoria lapidarios y escultores que sepan de traça y arquititura para que bean si en todo an cunplido con la traça y condiciones [...] nonbrando ansimismo los dichos maestros de su parte personas del dicho arte para que informen a los que nonbrare la dicha seńora marquesa yten que los dichos ocho mil ducados del precio de la dicha obra la dicha señora marquesa se los a de pagar en esta manera dos mil ducados luego para ir a las canteras y estando toda la piedra en la obra para començar a labrar otros dos mil ducados y estando la mitad de la obra asentada otros dos mil ducados y los otros dos mil ducados restantes se les an de pagar estando la obra acavada y dada por buena por las personas que su señoria nonbrare lo qual pagara su seńoria llanamente de contado [la marquesa garantiza el pago con una serie de juros y rentas...] [por 
su parte, los maestros dan por garantía...] yten una casa quel dicho cristobal velazquez tiene junto a la calle de la cruz que ace esquina con la dicha cruz y con casas de esteban del peso en que bibe y unas tierras de pan llebar con sus eras camino de medina del campo de cinco yguadas y un cercado junto al monesterio del corpus cristi desta ziudad de seus yguadas yten un majuelo del dicho francisco velazquez de trece alanzadas que tiene do dicen el ojo de nalda que linda con majuelo de muńoz y el camino de renedo yten la mitad de las casas en que bibe el dicho juan de muniategui en la calle del sacramento desta ciudad que es suya [...] 
